\title{
Robert Bárány, a scientist with many interests
}

\author{
Robert Bárány, um cientista com muitos interesses
}

Péricles MARANHÃO-FILHO', Anders BÁRÁNY²

\begin{abstract}
Austrian-born Robert Bárány was a scientist with many interests. This article highlights some of these interests and also some personal traits. He enrolled as a surgeon in World War I, was captured by the Russians in 1915 and, while still in the prison camp, was awarded the 1914 Nobel Prize in Physiology or Medicine for his work in otology. In 1916, he accepted an offer from Uppsala University, Sweden, and worked there for almost 20 years. He died shortly before his 60 ${ }^{\text {th }}$ birthday, in 1936.
\end{abstract}

Keywords: Robert Bárány; neurotology; neurosurgery.

\section{RESUMO}

O austríaco Robert Bárány foi um cientista com muitos interesses. Este artigo destaca alguns desses interesses e também alguns traços pessoais. Bárány se inscreveu como cirurgião na Primeira Guerra Mundial, foi capturado pelos russos em 1915 e, ainda no campo de prisioneiros, recebeu o Prêmio Nobel de 1914 em Fisiologia ou Medicina por seu trabalho otológico. Em 1916 aceitou uma oferta da Universidade de Uppsala, na Suécia, onde trabalhou por quase vinte anos. Ele faleceu em 1936, pouco antes de seu sexagésimo aniversário.

Palavras-chave: Robert Bárány; neuro-otologia; neurocirurgia.

Robert Bárány's father came from the Hungarian part of Austria-Hungary and his mother from the Czech part ${ }^{1}$. Robert, born in Vienna in 1876, was their oldest child and is said to have been shy and introspective. When young he was infected with tuberculosis, which resulted in ankylosis of the right knee.

Bárány studied Medicine in Vienna and graduated in 1900. During his studies he followed lectures by Sigmund Freud and became interested in brain research. He wanted to become a psychiatrist but was persuaded by his mother to become a surgeon", and started working at the Otolaryngology Clinic. There, Bárány devised and developed the caloric tests and the rotating chair for vestibular testing².

Besides his vestibular system research, Bárány also developed new clinical methods: in 1908, he described an approach for operating on acoustic nerve tumors and, in 1910, he developed a method for the surgical treatment of otosclerosis. In 1911, he became interested in the effects of alcohol on the sense of balance and demonstrated, for the first time, that alcohol can cause positional nystagmus.

Through his early work on the vestibular system, Bárány was quickly recognized by the scientific community, was invited to international conferences, and gave lectures abroad, including in Sweden. There he became a good friend of Gunnar Holmgren (about the same age as Bárány), a professor of otolaryngology at the Karolinska Institutet, the prize-awarding institution for the Nobel Prize in Physiology or Medicine. At the young age of 34, Bárány had already started receiving nominations for this Nobel Prize in 1910, and was nominated by Holmgren in 1913 and 1914 .

When World War I started, Bárány left his wife and two small boys in Vienna and registered as a civilian physician. He asked to be sent to the front, partly because he wanted to test his ideas on how to treat head wounds in a new and, hopefully, better way. At that time, traditional surgery mandated that a head wound was to be kept open, but Bárány argued for closing the wound immediately after cleaning. He was stationed in Fort Przemysl, which was surrounded and bombarded by Russian troops for several months. Many soldiers received head wounds and were treated by Bárány with his new procedure. He achieved good results and the first publication reporting this was flown out of Przemysl and published in Vienna ${ }^{4}$ and Tübingen ${ }^{5}$. In a privately written story of

${ }^{1}$ Universidade Federal do Rio de Janeiro, Hospital Universitário Clementino Fraga Filho, Departamento de Clínica Médica, Serviço de Neurologia, Rio de Janeiro RJ, Brasil;

Stockholm University, Stockholm, Sweden.

* Boman-Bárány M. Family notes, unpublished (in Swedish).

Péricles Maranhão-Filho iD https://orcid.org/0000-0003-2030-547X

Correspondence: Péricles Maranhão-Filho;Av. Prefeito Dulcídio Cardoso, 1680/1802; 22620-311 Rio de Janeiro RJ; E-mail:pmaranhaofilho@gmail.com Conflict of interest: There is no conflict of interest to declare.

Received 24 August 2018; Accepted 08 November 2018. 


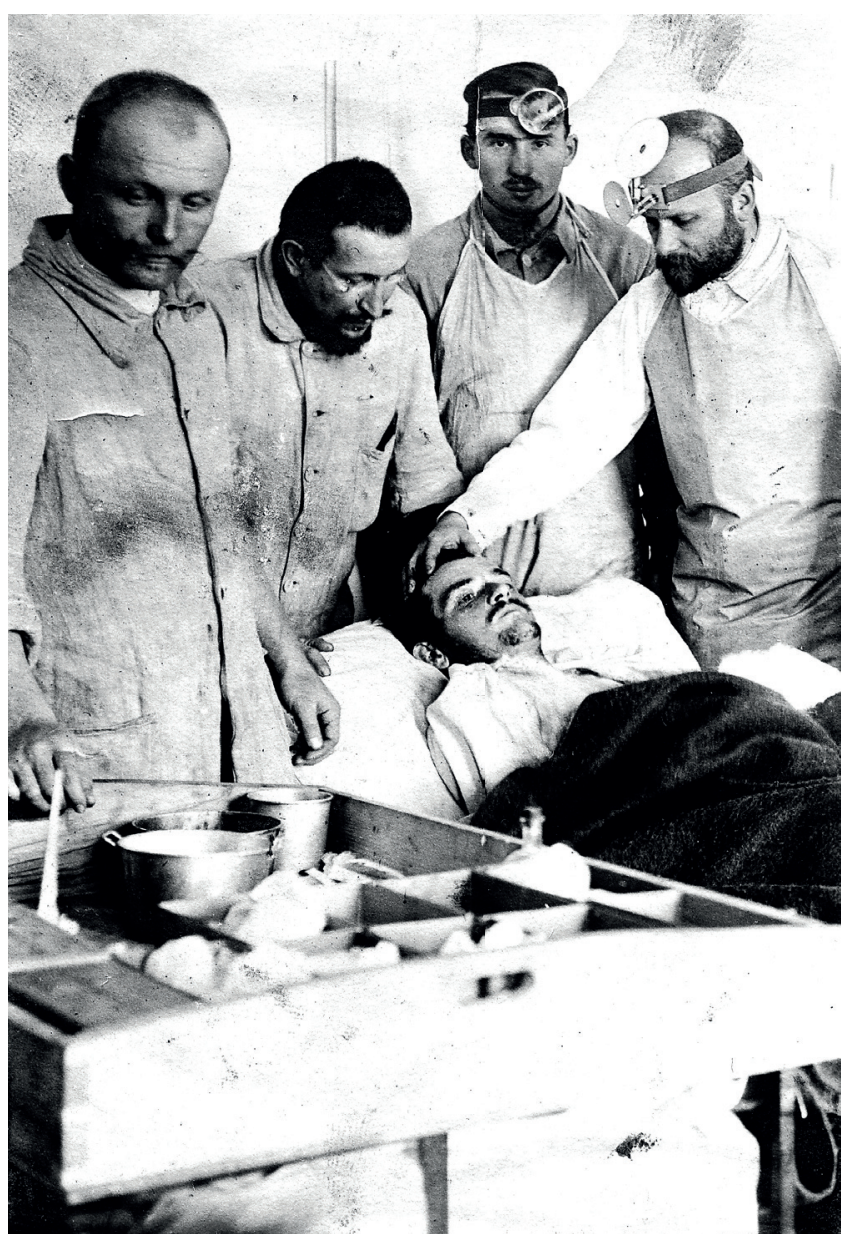

Figure 1. Robert Bárány (right). Photo supposedly taken in Przemysl 1914/1915. Photo from Robert Bárány's grandson Anders Bárány's family album.

his war experiences, Bárány described the time in Przemysl as "the best time of my life" (Figure 1).

The fort surrendered in April 1915, and he was transported to a prison camp in Merv, Turkestan. There he was allowed to treat both his fellow prisoners and the Russian personnel but, like many prisoners, he was infected with malaria. During this time, Bárány and his fellow officers had comfortable quarters and were well treated, but boredom made life in the prison camp almost unbearable. Physical games, such as tennis, could fill only a limited amount of time, while cards and similar games were distasteful to Bárány. In addition, no library existed with books in languages other than Russian ${ }^{6}$.

In November 1915, the Karolinska Institutet in Stockholm granted him the reserved 1914 Nobel Prize in Physiology or Medicine "for his work on the physiology and pathology of the vestibular apparatus". Bárány learned of the news through a telegram to the Russian prison camp. Prince Carl of Sweden, head of the Red Cross, helped Bárány to be moved to the University of Kazan, where he was allowed to

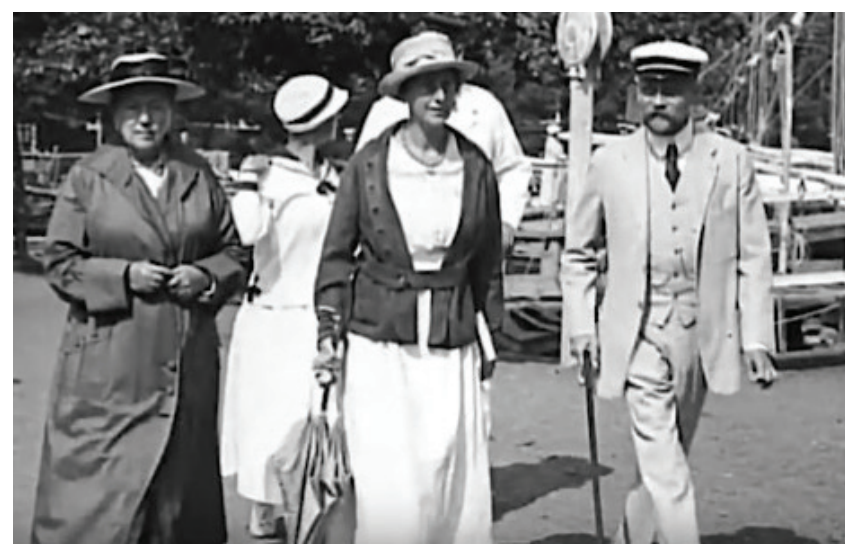

Figure 2. Robert Bárány with his wife and mother-in-law at the summer resort Sandhamn, 1920. Still from a video7, which, to our knowledge, is the only existing one of Robert Bárány and which has not been published outside Sweden before. The video belongs to Swedish Television SVT and can be seen in an online video available at:

https://www.youtube.com/watch?v=2Y2jQkqksOs

use the university library, open a clinic and treat patients. Finally, he obtained his liberation at Haparanda, on the Swedish-Russian border in June 1916. On his way home to Vienna, he stopped for a few days in Stockholm to lecture on his successful new way of treating head wounds. After the war, the American neurosurgeon, Harvey Cushing, reported similar good results, but priority goes to Bárány because of the rapid publication of his results from Przemysl ${ }^{8}$.

In the autumn of 1916, Bárány accepted an invitation to establish an otology clinic in Uppsala and, in 1917, he moved with his family, his wife Ida, his two sons, Ernst and Franz, and his wife's mother, to Sweden (Figure 2). A daughter, Ingrid, was later born in Uppsala. The life of Bárány was quite simple and he had only a small number of close friends. Learning Swedish was not a major problem for him, but both he and his wife longed for the cultural life in Vienna, especially the music ${ }^{6}$.

Bárány also had a deep interest in a purely intellectual endeavour - an attempt to develop a general theory of the function of the cerebral cortex. This was indeed an ambitious undertaking. His aim was to ascertain how cerebral mechanisms work by analysing the available knowledge of the morphology and connections of the cortical neurons ${ }^{6}$.

In the 1920s, Robert Bárány also started to take an interest in peace activities. He wanted to establish a Peace University in Switzerland, where politicians would be educated on how to make peace ${ }^{9}$. As a Nobel Laureate, he had the idea of sending letters to other Nobel Laureates asking them to engage in this task. At first, he got many positive answers, but when he also asked for some money for this purpose, the answers were less positive ${ }^{n * w}$. The idea of a Peace University was eventually

** Bárány R. Memories from war and being a Russian prisoner, unpublished (in Swedish).

*** Collection of Bárány letters and documents at the University Library of Uppsala, Sweden. 
concluded in 1927, financed by the Rockefeller Foundation. The former United Nations General Secretary, Kofi Annan, Nobel Peace Laureate in 2001, was one who spent time there.

In the last years of his life, with malignant hypertension, Bárány suffered multiple vascular accidents and died in Uppsala on April 8, 1936, a few days before reaching his $60^{\text {th }}$ birthday At the funeral, Gunnar Holmgren laid down a wreath with the text "To Robert Bárány, the genial scientist, thankfully from otologists all over the world”. Holmgren also said, among other remarks, "More than any now living, you have contributed to the development of our science; your restless, burning soul saw clearly where we others fumbled in the darkness" ${ }^{10}$.

\section{ACKNOWLEDGMENT}

The authors thank Mr. Péricles Maranhão Neto for help in making a short video of Robert Bárány suitable for publication on YouTube ${ }^{7}$.

\section{References}

1. Gunter J. Robert Bárány (1876-1936) Leben und Werk. Frankfurt: Peter Lang; 1997

2. Bárány R. Physiologie und Pathologie (Funktionsprüfung) des Bogengangapparates beim Menschen: Klinische Studien., Leipzig: Franz Deuticke; 1907

3. Robert Bárány Nobel Prize. Available from: http://www.nobelprize.org

4. Bárány R. Primäre Wundnaht bei Schußverletzungen, speziell des Gehirnes, Wien klin Wschr. 1915;28:525.

5. Bárány R. Die offene und geschlossene Behandlung der Schußverletzungen des Gehirns. Beitr. klin. Chr. Tübingen 1915;97:397.
6. Lorente de Nó R. Facets of the life and work of professor Robert Bárány (1886-1936). In: Graham MD, Keimink JL (editors). The vestibular system. New York, NY: Raven Press; 1985. p. 12-6.

7. Robert Bárány: his wife Ida, and his mother-in-law Katharina Berger. 1920. Available from: https://www.youtube.com/watch?v=2Y2jQkqksOs

8. Carey ME. Cushing and the treatment of brain wounds during World War I. J. Neurosurg. 2011;115:1495.

9. Lettevall R. Fredsuniversitetet. [cited 2018 Aug 3]. Available from: https://www.diva-portal.org/smash/get/diva2:214428/FULLTEXT01.pdf

10. Holmgren G. Robert Bárány. Nordisk Medicinsk Tidskrift, 1936;11:865. 